\section{The North Carolina State University}

(NCSU) Libraries have received a $\$ 313,000$ grant to develop a roadmap for how 21stcentury libraries can best give a competitive edge to faculty, researchers, graduate students, and a new generation of alwaysconnected, technology-savvy, and highly engaged undergraduates. Enabled by the support of a National Leadership Grant from the Institute of Museum and Library Services (IMLS), the NCSU Libraries will lead a collaborative project to prototype, develop, and disseminate plans for how mobile technologies, gesture-based computing, large-scale visualization, enhanced reality, and other emerging technologies can help academic libraries create the next generation of technology-rich collaborative learning spaces.

\section{The Columbia University Libraries have}

received a gift of $\$ 4$ million to establish the Norman E. Alexander Library for Jewish Studies, which will include three new endowments: a Jewish Studies librarian, the General Jewish Studies Collection, and the Special Collections in Judaica. Alexander graduated from Columbia University in 1934 and Columbia Law School in 1936, after which he set off on a business career that spanned seven decades. When he died in 2006, he was executive chairman of Sequa Corporation, a $\$ 2$ billion conglomerate that he led for nearly 50 years. A lifelong supporter of academic, Jewish, and other philanthropic causes, Alexander was a member of the Board of Visitors of Columbia Law School and of the Board of Columbia/Barnard Hillel, where he established the Alexander Program Center for Jewish Life. The new Norman E. Alexander

Ed. note: Send your news to: Grants \& Acquisitions, C\&RL News, 50 E. Huron St., Chicago, IL 60611-2795; e-mail: agalloway@ala.org.
Librarian for Jewish Studies is Michelle Chesner. She joined the Columbia Libraries in May 2010, coming from the University of Pennsylvania where she served as an archivist and as the Judaica public services librarian at the Katz Center for Advanced Judaic Studies. The new Norman E. Alexander Library for Jewish Studies in special collections builds on a strong tradition of rare book and archival resources, including 29 Hebrew incunabula, more than 300 sixteenth-century printed books, and nearly 1,500 Hebrew manuscripts, plus extensive archival collections related to Jewish life and culture, and Jewish individuals in all fields of study and work. The Jewish Studies research collections at Columbia exceed 100,000 monograph volumes and 1,000 current and historical periodical titles. The collection comprises about 60,000 Hebrew and Yiddish titles in addition to its large holdings of Jewish scholarly works in Western and Slavic languages.

\section{Acquisitions}

\section{The Junior League of Los Angeles, one} of the oldest women's philanthropic organizations in the city, has donated its archives to California State UniversityNorthridge (CSUN). The collection, which will be housed in CSUN's Oviatt Library's Urban Archives Center, offers insight into the history of women and philanthropy in Los Angeles since the organization's inception in 1925. The collection includes photographs, correspondence, minutes of meetings, scrapbooks, film, videos, and other memorabilia that chronicle the 85 years the Junior League and its members have tried to make a difference in the lives of women and children living in Los Angeles. $n$ 